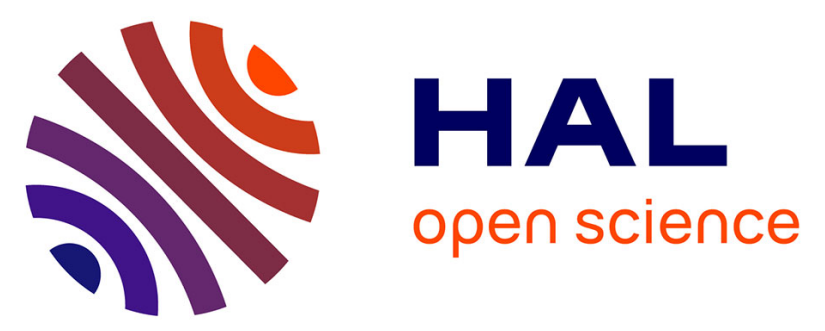

\title{
Developmental delay and connective tissue disorder in four patients sharing a common microdeletion at 6q13-14
}

Hilde van Esch, Elisabeth M Rosser, Sandra Janssens, Ingrid van Ingelghem, Bart Loeys, Björn Menten

\section{- To cite this version:}

Hilde van Esch, Elisabeth M Rosser, Sandra Janssens, Ingrid van Ingelghem, Bart Loeys, et al.. Developmental delay and connective tissue disorder in four patients sharing a common microdeletion at 6q13-14. Journal of Medical Genetics, 2010, 47 (10), pp.717. 10.1136/jmg.2010.077586 . hal00557396

\section{HAL Id: hal-00557396 https://hal.science/hal-00557396}

Submitted on 19 Jan 2011

HAL is a multi-disciplinary open access archive for the deposit and dissemination of scientific research documents, whether they are published or not. The documents may come from teaching and research institutions in France or abroad, or from public or private research centers.
L'archive ouverte pluridisciplinaire $\mathbf{H A L}$, est destinée au dépôt et à la diffusion de documents scientifiques de niveau recherche, publiés ou non, émanant des établissements d'enseignement et de recherche français ou étrangers, des laboratoires publics ou privés. 


\section{Developmental delay and connective tissue disorder in four patients sharing a common microdeletion at $6 q 13-14$}

Hilde Van Esch ${ }^{1}$, Elisabeth M Rosser ${ }^{2}$, Sandra Janssens ${ }^{3}$, Ingrid Van Ingelghem ${ }^{4}$, Bart Loeys ${ }^{3}$, Bjorn Menten $^{3}$

1. Centre for Human Genetics, University Hospitals Leuven, Leuven, Belgium

2. Clinical Genetics, Great Ormond Street Hospital, London, WC1N 3EH UK

3. Centre for Medical Genetics, Ghent University Hospital, Ghent, Belgium

4. Pediatric Department, AZ KLINA, Brasschaat, Belgium

*Corresponding author: Hilde Van Esch, MD, PhD

Centre for Human Genetics

University Hospitals Leuven

Herestraat 49

3000 Leuven, Belgium

Tel: $+32-16-345903$

Fax: +32-16-346051

E-mail: Hilde.Vanesch@med.kuleuven.be

Running title: Deletion 6q13-14 and connective tissue disorder

Words in abstract: 110

Words in main text: 1986

References: 18

Figures: 1

Tables: 2 of which 1 supplementary

Key words: chromosome $6 q$, microdeletion, developmental delay, connective tissue, collagen, COL12A1

Competing Interest: None declared. 


\section{Abstract}

Interstitial deletions of the long arm of chromosome 6 are rare, and most of the reported cases represent large, cytogenetically detectable deletions. The implementation of array comparative genome hybridisation in the diagnostic work-up of patients presenting with congenital disorders including developmental delay has enabled the identification of many patients with smaller chromosomal imbalances. Here we present 4 patients with a de novo interstitial deletion of chromosome $6 q 13-14$, resulting in a common microdeletion of $3.7 \mathrm{Mb}$. All patients present with developmental delay, mild dysmorphism and signs of lax connective tissue. Interestingly, the common deleted region harbours 16 genes of which the COL12A1 represents a good candidate for the connective tissue pathology. 


\section{Introduction}

A detailed phenotypic description of small interstitial $6 q$ deletions is hampered by the scarcity of such patients and most of the reported cases represent large, cytogenetically detectable deletions [1]. The widespread use of array comparative genome hybridisation (array-CGH) in the diagnostic work-up of patients presenting with congenital disorders including developmental delay has enabled the identification of many patients with smaller chromosomal imbalances [2]. It moreover permitted the identification and delineation of new microdeletion and microduplication syndromes, allowing a more detailed assessment of the phenotypic consequences associated with specific chromosomal imbalances. The present report describes the genotypic and phenotypic delineation of four patients with a de novo interstitial deletion of chromosome $6 q 13-14$, resulting in a common microdeletion of 3.7 Mb. All patients present with developmental delay, mild dysmorphism and signs of lax connective tissue. Interestingly, the COL12A1 gene that maps within the common deleted region constitutes a good candidate for the connective tissue pathology.

\section{Clinical description}

\section{Patient 1}

The girl was born at 35 weeks gestation by spontaneous delivery after an uncomplicated pregnancy to healthy, unrelated parents. Family history is unremarkable. At birth, both feet were in an extreme dorsiflexion position and she had a fibromatosis colli, both necessitating physiotherapy. Initially, feeding was difficult because of general hypotonia with poor sucking. Motor development was delayed because of this hypotonia as well as the presence of hyperlaxity in hips and large joints. She sat with her thighs internally rotated and her knees flexed. She started to crawl at 21 months. In addition, her speech development was delayed with the use of only a few words at the age of two. At her last clinical examination, at the age of 2 years, the growth parameters were all within the normal range. She has mild motor delay and moderate language delay (level of 18 months at age 24 months). She has a high-pitched voice and shows good social contact. Hyperlaxity is still present and she has a pronounced lordosis and bilateral pes plani. She also has mild dysmorphic features including a high forehead, long philtrum with thin upper vermillion, broad neck and sacral dimples (Figure 1A). Brain imaging and EMG were normal, but on radiographs of the spine an anterolisthesis L2-L3 was seen. Because of the hyperlaxity and developmental delay, Larsen syndrome was initially suspected.

Patient 2 
This boy was born at 37 weeks of pregnancy. He was hospitalized on the neonatal ward because of low birth weight $(2300 \mathrm{~g}$ ) and repetitive hypoglycemia. He was the first and only child of unrelated healthy parents. Family history revealed borderline mental impairment present in the brother of the father and in his maternal uncle. At the age of 3 years an inguinal unilateral hernia was surgically corrected. His psychomotor development was characterized by walking at 22 months and delayed speech development. He was referred at the age of 5 years because of his delay with an IQ of 50-55. Clinical examination at that age showed a boy with growth parameters in the high-normal range. Hyperlaxity was present in fingers, wrists and elbows together with bilateral pes plani with short toes and a mild pectus excavatum. He had mild dysmorphic features including long philtrum with thin upper vermillion, large earlobes, mild synophris and a metopic ridge (Figure 1B). Brain imaging, EEG, echocardiography, radiograph of the spine and metabolic work-up were all normal.

\section{Patient 3}

This girl was born at term after an uneventful pregnancy. The neonatal period was complicated by a necrotizing enterocolitis. Because of facial dysmorphism, she was seen by a clinical geneticist at the age of 2 months. Several dysmorphic signs were noted: low frontal hair line, high nasal bridge, long philtrum with thin upper lip, low-set posterior rotated ears, high palate and retrognathia. Her thorax was short and an umbilical hernia was present. She had bilateral tri-phalangeal thumbs and broad distal phalanges. She presented with a bilateral nystagmus, axial hypotonia and hands in a fist position. Re-examination at the age of 5 months showed axial hypotonia as well as hyperlaxity, and length and weight below the third centile. She suffered from recurrent respiratory infections. A bilateral sensorineural hearing loss of $55 \mathrm{~dB}$ was documented. Ultrasound of the brain showed a small periventricular hemorrhage. Ultrasound of the abdomen showed bilateral small kidneys. Radiograph of the skull and spine were normal. She died at the age of 8 months of unknown cause, post-mortem examination was refused by the parents.

\section{$\underline{\text { Patient } 4}$}

This boy is the second child of healthy unrelated parents, with no family history of note. He was born after an unremarkable pregnancy at 38 weeks gestation by planned Caesarian, because of breech position. He was noted to have undescended testes and hypotonia. Chromosome analysis was performed at 20 months of age because of motor delay and dysmorphic features. This showed an apparently balanced translocation, 46,XY t(2:6)(q31;q15). When he was seen in clinic he was noted to have marked joint laxity, a smooth philtrum, thin upper vermillion, upturned nose with anteverted nostrils, large ears, pointed chin and $5^{\text {th }}$ finger clinodactyly (Figure $1 C, D$ ). At the age of 6 years he was found to have hypogonadotrophic hypogonadism (not Kallman's) and was referred back to the 
genetics clinic. At that time his parents reported that he was making slow but steady progress. He attended a special school and had some difficulties with fine motor skills. His biggest problem was walking; he had begun to walk at $3 \frac{1}{2}$ years but still frequently fell due to eversion at the ankles. On examination, his facial features were as described before. He continued to have generalized joint laxity and had mild truncal obesity. His feet appeared small for his size with bilateral pes cavus. He held his feet in eversion with both halluces pointing upwards. A hard swelling was present on the lateral side of each foot which has been ascribed to the fact that his weight bears along the lateral side of the feet. Ophthalmological examination was normal.

\section{Methods}

The protocol was approved by the appropriate Institutional Review Board of the University Hospitals of Leuven and Ghent in Belgium, and the Institute of Child Health London, and informed consent was obtained from the parents of the affected patients. Written consent was given to the authors for publication of the patient's images in print and online. Genomic DNA of each patient and the parents was isolated according to standard procedures.

Standard cytogenetic analysis showed normal karyotypes for patients 1, 2 and 3. In patient 4 an apparently balanced de novo translocation, $46, \mathrm{XY}, \mathrm{t}(2: 6)(\mathrm{q} 31 ; \mathrm{q} 15)$ was detected.

The genomic DNA of patients 1 and 4 was analyzed on the total genome $1 \mathrm{Mb}$ BAC array. Clone preparation, hybridization and data analysis were performed as previously described [3]. Both patients 2 and 3 were analyzed using the Agilent Human Genome CGH 44k array [2]. All genome coordinates mentioned in this study are according to human genome build 18 (NCBI 36.1). The inheritance of each of these deletions was investigated by analyzing parental samples using microarrays (patients 1 and 2) or karyotyping and FISH analysis (patients 3 and 4).

\section{Results}

In the absence of an etiological diagnosis in patients 1, 2 and 3, array-CGH analysis was performed. Regarding patient 4, array analysis was performed to query the balanced nature of the chromosomal rearrangement. Table 1 summarizes the clinical and molecular findings in the 4 patients. All patients carry overlapping deletions of variable size spanning the 6q13-14 region (Figure 1F). The shortest region of overlap (SRO) is defined by the proximal breakpoint at $72.65 \mathrm{Mb}$ in patient 2 and the distal breakpoint at $76.31 \mathrm{Mb}$ in patient 1 . This critical region is $3.66 \mathrm{Mb}$ in size and contains 16 annotated genes (Table 2, supplementary). All deletions have arisen de novo.

\section{Discussion}


Since the introduction of array-CGH technology, the rate of discovery of novel genomic imbalances has increased dramatically. New disorders are described by their genomic rearrangement and subsequently, clinical features are compared among patients when a common imbalance is identified. In this regard, the use of worldwide databases of chromosomal imbalances such as DECIPHER, has greatly facilitated the identification of additional patients, as in our cases [4].

Interstitial deletions involving chromosome 6q13-14 are rare with eight patients reported to date [512]. Here, we present four more patients that were analyzed by array-CGH because of developmental delay and facial dysmorphism. By comparing the facial features, we could distinguish some common features, namely long philtrum, th in upper vermillion, pointed chin and large ear lobes (Figure 1). All patients presented with developmental delay with hypotonia, the latter symptom especially in the first years of life. In the older reported patients language and motor delay were noted, with severity correlating with the deletion sizes.

Interestingly, in each patient marked joint laxity was noticed by the respective clinical geneticist, and in patient 1 even the diagnosis of Larsen syndrome was suggested. This hyperlaxity was also noted in some of the older reported patients, with dislocation of the hips in three patients, and flatfeet in two [5-7, 10-12]. In addition, in the majority of patients, other features of loose connective tissue were present, including umbilical and inguinal hernia and thorax and foot deformities. Within the SRO deletion, the COL12A1 gene is present, which encodes the alpha chain of type XII collagen, a member of the FACIT (fibril-associated collagens with interrupted triple helices) collagen family. Type XII collagen is a homotrimer found in association with type I collagen, an association that is thought to modify the interactions between collagen I fibrils and the surrounding matrix. Expression analysis in zebrafish showed that collagen type XII is broadly expressed in many connective tissues including fascia and basement membranes [13]. Moreover, sequence variants within COL12A1 have recently been associated with increased risk of ligament ruptures in a case-control genetic association study [14]. To date, COL12A1 has not been implicated in human disease, to our knowledge, and no mouse model is available. Our finding might represent the first association between haploinsufficiency of the COL12A1 gene and a possible human phenotype. Further sequencing analysis in a large group of patients with similar connective tissue pathology as well as the development of a mouse model will enable us to confirm these results and open the way to exactly define the phenotype associated with this collagen gene.

Other interesting genes within the common defined deletion are KCNQ5, a voltage dependent potassium channel and member of a very large family of potassium channels of which some have been linked to diseases including cardiac arrhythmias, deafness and epilepsy [15] and SLC17A5 (Table 


\begin{tabular}{|c|c|c|c|c|c|}
\hline Patient & 1 & 2 & 3 & 4 & Lespinasse et al.[12] \\
\hline DECIPHER & & 00002719 & 00000863 & 00000140 & \\
\hline Sex & $\mathrm{F}$ & M & $\mathrm{F}$ & M & $\mathrm{F}$ \\
\hline size deletion & $68213162-76318818$ & $72654054-76925922$ & $72157311-97184863$ & $72157311-80953422$ & $73112000-80988000$ \\
\hline Birth & 35 weeks & 37 weeks & term & 38 weeks & 39 weeks \\
\hline weight & $3005 \mathrm{~g}$ & $2300 \mathrm{~g}$ & $2350 \mathrm{~g}$ & $\mathrm{NI}$ & $3780 \mathrm{~g}$ \\
\hline lenght & $47 \mathrm{~cm}$ & $47.5 \mathrm{~cm}$ & $47 \mathrm{~cm}$ & $\mathrm{NI}$ & $53 \mathrm{~cm}$ \\
\hline OFC & $34 \mathrm{~cm}$ & $\mathrm{NI}$ & $35 \mathrm{~cm}$ & $\mathrm{NI}$ & $37 \mathrm{~cm}$ \\
\hline Age at first clinical exam & 16 months & 5 years & 2 months & 23 months & 30 months \\
\hline Developmental delay & + & + & + & + & + \\
\hline Motor delay, hypotonia & + & + & + & + & + \\
\hline Mental level & mild delay & $I Q=55$ & too young to assess & moderate delay & $\mathrm{IQ}=70$ \\
\hline Facial dysmorphism & & & & & \\
\hline thin upper lip & + & + & + & + & \\
\hline smooth long philtrum & + & + & + & + & \\
\hline low frontal hair line & & & + & & \\
\hline high palate & + & & + & & \\
\hline retrognathia & & & + & & + \\
\hline high nasal bridge & + & & + & & \\
\hline $\begin{array}{r}\text { low set ears } \\
\text { other }\end{array}$ & + & + & + & epicanthus, prominent ears & $\begin{array}{c}+ \\
\text { epicanthus, hypotelorism }\end{array}$ \\
\hline Growth parameters/age & 16 months & 5 years & 2 months & 23 monts & 10 years \\
\hline weight & 10.5 kg (P50) & $18.2 \mathrm{~kg}(\mathrm{P} 75)$ & $3220 \mathrm{~g}(<\mathrm{P} 3)$ & $14.5 \mathrm{~kg}$ (P90) & 40 kg (>P90) \\
\hline lenght & $81 \mathrm{~cm}($ P75) & $108.5 \mathrm{~cm}(\mathrm{P} 50)$ & $50 \mathrm{~cm}(<\mathrm{P} 3)$ & $81 \mathrm{~cm}(\mathrm{P} 3)$ & $149 \mathrm{~cm}(>\mathrm{P} 90)$ \\
\hline OFC & 47 cm (P50) & $52 \mathrm{~cm}(\mathrm{P} 90)$ & $37.4 \mathrm{~cm}(\mathrm{P} 25)$ & $49 \mathrm{~cm}(\mathrm{P} 10)$ & $54 \mathrm{~cm}(>\mathrm{P} 90)$ \\
\hline $\begin{array}{l}\text { Joint laxity (all joints) } \\
\text { thorax }\end{array}$ & $+(L L>U L)$ & $\stackrel{+}{\text { mild pectus }}$ & $\stackrel{+}{+}$ & + & $\stackrel{+}{\text { pectus excavatum }}$ \\
\hline loose connective tissue & talipes equinovarus & $\begin{array}{l}\text { excavatum } \\
\text { inguinal henia }\end{array}$ & umbilical hernia & pes cavus & $\begin{array}{l}\text { umbilical hernia } \\
\text { cubitus valgus } \\
\text { flat valgus feet }\end{array}$ \\
\hline $\begin{array}{l}\text { Urogenital anomalies } \\
\text { Other }\end{array}$ & $\begin{array}{l}\text { VUR grade } 2-3 \\
\text { high pitched voice } \\
\text { sacral dimple }\end{array}$ & sacral dimple & $\begin{array}{c}\text { small kidneys } \\
\text { neonatal enterocolitis } \\
\text { nystagmus } \\
\text { died at } 8 \text { months } \\
\text { recurrent respiratory } \\
\text { infections }\end{array}$ & $\begin{array}{c}\text { cryptorchidism } \\
\text { hypogonadotr. hypogonadism } \\
\text { obesity }\end{array}$ & \\
\hline
\end{tabular}

Ider published
cases [5-11]

$3 \mathrm{M} / 4 \mathrm{~F}$ 
2). Mutations in the latter gene cause an autosomal recessive lysosomal free sialic acid storage disease [16]. Lespinasse and co-authors suggested that the $5-H T 1 B$ gene could be responsible for the mental retardation and language delay observed in 6q13-14del patients [12]. This gene encodes a hydroxytryptamine receptor and these type of receptors have been implicated in a variety of neuropsychiatric disorders [17]. It maps $2 \mathrm{Mb}$ telomeric to the common defined deleted region and is deleted in two of our patients. We can not exclude a role for this gene in the developmental delay of these patients, but given the fact that the two other patients also clearly exhibit a developmental delay, another gene(s) within the SRO should also be involved. In this regard the FILIP gene encoding a Filamine A-interacting protein involved in cortical cell migration represents an interesting candidate [18]. Yet, neither of our patients shows neuronal migration defects on MRI scan of the brain.

Another feature present in the majority of patients is urogenital anomalies with cryptorchidism reported in three out of the five male patients. In patient 4, this cryptorchidism is probably due to the documented hypogonadotrophic hypogonadism.

Our analysis of four cases of 6q13-14 microdeletion defines a novel site of copy number variation associated with developmental delay, distinct facial features and connective tissue pathology. The latter feature in particular may constitute a good clinical handle to identify additional patients.

\section{Acknowledgements}

The authors wish to thank the patients and families for their cooperation. H.V.E. and B.L. are clinical investigators funded by F.W.O. Vlaanderen. We do not have any affiliation with any group with a direct financial interest in the subject matter or materials discussed in the manuscript.

\section{Copyright licence statement}

The corresponding author has the right to grant on behalf of all authors and does grant on behalf of all authors, an exclusive licence on a worldwide basis to the BMJ Group and co-owners or contracting owning societies (where published by the BMJ Group on their behalf), and its Licensees to permit this article (if accepted) to be published in Journal of Medical Genetics and any other BMJ Group products and to exploit all subsidiary rights, as set out in our licence. 


\section{References}

1. Zherebtsov MM, Klein RT, Aviv H, Toruner GA, Hanna NN, Brooks SS. Further delineation of interstitial chromosome 6 deletion syndrome and review of the literature. Clin Dysmorphol 2007;16(3):135-40.

2. Buysse K, Delle Chiaie B, Van Coster R, Loeys B, De Paepe A, Mortier G, Speleman F, Menten B. Challenges for CNV interpretation in clinical molecular karyotyping: Lessons learned from a 1001 sample experience. Eur J Med Genet 2009.

3. Menten B, Maas N, Thienpont B, Buysse K, Vandesompele J, Melotte C, de Ravel T, Van Vooren S, Balikova I, Backx L, Janssens S, De Paepe A, De Moor B, Moreau Y, Marynen P, Fryns JP, Mortier G, Devriendt K, Speleman F, Vermeesch JR. Emerging patterns of cryptic chromosomal imbalance in patients with idiopathic mental retardation and multiple congenital anomalies: a new series of 140 patients and review of published reports. J Med Genet 2006;43(8):625-33.

4. Firth HV, Richards SM, Bevan AP, Clayton S, Corpas M, Rajan D, Van Vooren S, Moreau Y, Pettett RM, Carter NP. DECIPHER: Database of Chromosomal Imbalance and Phenotype in Humans Using Ensembl Resources. Am J Hum Genet 2009;84(4):524-33.

5. McNeal RM, Skoglund RR, Francke U. Congenital anomalies including the VATER association in a patient with del(6)q deletion. J Pediatr 1977;91(6):957-60.

6. Young RS, Fidone GS, Reider-Garcia PA, Hansen KL, McCombs JL, Moore CM. Deletions of the long arm of chromosome 6: two new cases and review of the literature. Am J Med Genet $1985 ; 20(1): 21-9$.

7. Gershoni-Baruch R, Mandel H, Bar El H, Bar-Nizan N, Borochowitz Z, Dar H. Interstitial deletion (6)q13q15. Am J Med Genet 1996;62(4):345-7.

8. Romie SS, Hartsfield JK, Jr., Sutcliffe MJ, Dumont DP, Kousseff BG. Monosomy 6q1: syndrome delineation. Am J Med Genet 1996;62(2):105-8.

9. Hopkin RJ, Schorry E, Bofinger M, Milatovich A, Stern HJ, Jayne C, Saal HM. New insights into the phenotypes of $6 q$ deletions. Am J Med Genet 1997;70(4):377-86.

10. Kumar R, Riordan D, Dawson AJ, Chudley AE. Proximal interstitial 6q deletion: a recognizable syndrome. Am J Med Genet 1997;71(3):353-6.

11. Myers SM, Challman TD. Proximal 6q interstitial deletion without severe mental retardation. Genet Couns 2005;16(3):269-76.

12. Lespinasse J, Gimelli S, Bena F, Antonarakis SE, Ansermet F, Paoloni-Giacobino A. Characterization of an interstitial deletion 6q13-q14.1 in a female with mild mental retardation, language delay and minor dysmorphisms. Eur J Med Genet 2009;52(1):49-52. 
13. Bader HL, Keene DR, Charvet B, Veit G, Driever W, Koch M, Ruggiero F. Zebrafish collagen XII is present in embryonic connective tissue sheaths (fascia) and basement membranes. Matrix Biol 2009;28(1):32-43.

14. Posthumus M, September AV, O'Cuinneagain D, van der Merwe W, Schwellnus MP, Collins $\mathrm{M}$. The association between the COL12A1 gene and anterior cruciate ligament ruptures. $\mathrm{Br} \mathrm{J}$ Sports Med 2009.

15. Jentsch TJ. Neuronal KCNQ potassium channels: physiology and role in disease. Nat Rev Neurosci 2000;1(1):21-30.

16. Verheijen FW, Verbeek E, Aula N, Beerens CE, Havelaar AC, Joosse M, Peltonen L, Aula P, Galjaard H, van der Spek PJ, Mancini GM. A new gene, encoding an anion transporter, is mutated in sialic acid storage diseases. Nat Genet 1999;23(4):462-5.

17. Sari Y. Serotonin1B receptors: from protein to physiological function and behaviour. Neurosci Biobehav Rev 2004;28:565-582.

18. Nagano T, Yoneda T, Hatanaka Y, Kubota C, Murakami F, Sato M. Filamin A-interacting protein (FILIP) regulates cortical cell migration out of the ventricular zone. Nat Cell Biol 2002;4(7):495-501. 
Legends to the figures

\section{Figure 1}

A-D: Clinical pictures of patient 1 at the age of 21 months (A), patient 2 at the age of 5 years (B), and patient 4 at the age of 6 years (C,D). Note the facial features they have in common: long philtrum, thin upper vermillion, high nasal bridge, short and upturned nose, epicanthal folds, pointed chin and large ears with large earlobes.

Lower panel: Schematic overview of the 6q13-14 region and different overlapping deletions.

Black bars indicate the microdeletion in the respective patient, grey bar indicates the breakpoint containing region; the shortest region of overlap (SRO) is indicated by the arrow; the patient reported by Lespinasse [12] is indicated by a grey bar; lower part shows a view of the UCSC genome browser (NCBI build 36.1, March 2006) illustrating the genes that map within the SRO.

Written consent was given to the authors for publication of the patient's images in print and online.

\section{$\underline{\text { Table } 1}$}

Overview of molecular and clinical data of the new and reported patients with a microdeletion 6q1314. Reported patients are referenced in [5-12]. Abbreviations: F: female; M: male; +: present; NI: no information; LL: lower limbs; UL: upper limbs; VUR: vesico-uretral reflux; hypogonadotr.:

hypogonadotrophic. Genome coordinates are according to human genome build 18 (NCBI 36.1), except for the patient reported by Lespinasse et al. (human genome build 17, NCBI35).

Table 2 Supplementary

List of the reference genes present in the shortest region of deletion overlap at $6 q 13-q 14.1$, based on human genome build 18 (NCBI 36.1). 

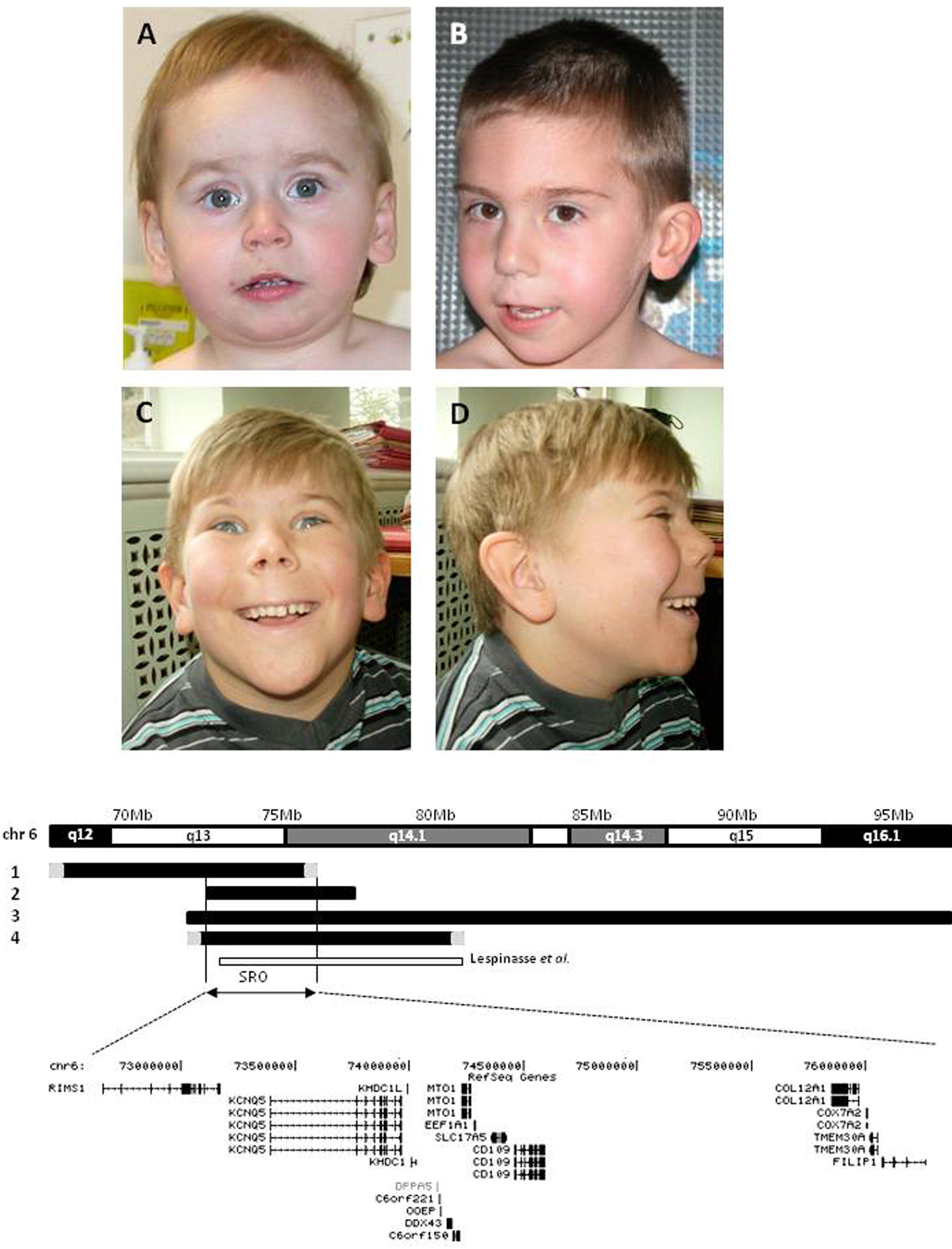